Dr. Muhammad Jalal Khalifa

\title{
Things Fall Apart: Post-Apocalyptic Vision in Cormac McCarthy's The Road
}

\author{
By
}

Dr. Muhammad Jalal Khalifa

Azzagazig University

Dept. of English

Cell : 01115501222

Email.drmuhammadjalal@yahoo.com

At noon in the desert a panting lizard waited for history, its elbows tense, watching the curve of a particular road as if something might happen.

It was looking for something farther off than people could see, an important scene

acted in stone for little selves at the flute end of consequences.

There was just a continent without much on it

under a sky that never cared less.

Ready for a change, the elbows waited The hands gripped hard on the desert. William Stafford "At the Bomb Testing Site" (1960)

When it was published in 2006, Cormac McCarthy's The Road won the Pulitzer Prize for fiction and was immediately recognized as one of the most interesting novels ever written. The protagonists of the novel are a nameless father and a nameless son who trek through a landscape that has been devastated by an apocalyptic event. This novel is McCarthy's most cataclysmic representation of post- 


\section{Things Fall Apart: Post-Apocalyptic Vision in Cormac}

McCarthy's The Road

apocalyptic unrelieved suffering and horror. Ryan makes it clear that McCarthy portrays post-apocalyptic suffering "with bleak, precise eloquence that builds anticipation and gradually accelerates readers toward an unexpected conclusion." Moreover, Sebastian Smee wrote: "More than an allegory or fantasy, The Road is a frighteningly credible novel. In some ways, I wish I had not read it." This is a study that proposes a post-apocalyptic interpretation of Cormac McCarthy's The Road. Major questions that led to this study include: What is post-apocalypse? How did it start and evolve? How can contemporary fiction respond to postapocalyptic disasters? Does The Road embody the postapocalyptic genre quite blatantly? Does the post-apocalyptic reading of The Road offer a better way of understanding the novel?

The term apocalypse is derived from Saint John's Book of Revelation, also known as the Apocalypse of John, which depicts a final cataclysm as heralding the end of the world. The Bible reverberates with many predictions that reinforce this apocalyptic promise. According to A New Handbook of Literary Terms, the term "apocalyptic" comes from the Greek word "apokalupsis" which literally means "an opening up or revealing" (21). In addition, Glasson defines the term as "an uncovering, an unveiling, either (a) of future events, or (b) of the unseen realms of heaven and hell" (1). In this perspective, the Book of Revelation reveals or unveils some of the mysteries of the future. According to Detweiler, "such revelation is always of a violent eruption of natural and supernatural powers, usually involving the destruction of the world, so that apocalypse has also come to mean the event of final cataclysm" (154). On the other hand, Miller argues that "what the apocalypse unveils is not the 
truth of the end of the world it announces but the act of unveiling. The unveiling unveils unveiling" (Heart 48). Thus, apocalypse is an uncovering or an "unveiling of what is going to be revealed at the end of the world" (Heart 33-4).

Collins makes it clear that "a corpus of texts that has been traditionally called 'apocalyptic' does indeed share a significant cluster of traits that distinguish it from other works" (4). He discusses two types of apocalypses: the historical apocalypses and the otherworldly journeys. The historical apocalypses "view the course of history from the perspective of supernatural forces and the coming judgment" (Collins 116). On the other hand, an otherworldly apocalypse is "expressed in the form of heavenly revelations to an ancient seer" (Collins 147). However, both types of apocalypses show "interest in the heavenly world" (Collins 24). Collins has, in effect, defined an apocalyptic text as:

a genre of revelatory literature with a narrative framework, in which a revelation is mediated by an otherworldly being to a human recipient, disclosing a transcendent reality which is both temporal, insofar as it envisages eschatological salvation, and spatial insofar as it involves another, supernatural world. (5)

Of greatest significance in this definition of apocalypse is the fact that it refers to "supernatural revelations" conveyed by "a supernatural being," revelations that affirm the inevitable defeat "of the wicked," the "final judgment" (6) of the universe, and the establishment of "a new creation, new heavens and a new earth" (Collins 24).

In contrast to Collins' limited perspective, John May is more open to multiple interpretations of apocalypse 
offering two kinds of the term: classical (primitive and Judeo-Christian) and modern secular apocalypse. While the former honors the sacred and contains three elements: catastrophe, judgment, and renewal, the latter reflects lack of religious faith. On the one hand, religious apocalyptic vision of life asserts that "the cosmos is ordered, that evil and suffering will be destroyed, that human existence is meaningful, and that a millennial realm of peace and justice ultimately will be created" (Wojcik 4). Not only do traditional religious forms of apocalypse bring meaning and order to life, but they are also able to create a "periodic reenactment of the cosmogony" which leads to "a purifying effect" (May 7) that evokes a sense of rebirth and renewal. According to Judeo-Christian imagination, "renewal means not just beginning again but actual growth or development. What is new is genuinely new because time is irreversible" (May 8).

On the other hand, apocalypse - in its modern secular version-ignores religious belief. If classical or religious apocalypse comprises both catastrophe and the possibility of renewal or hope, secular apocalypse emphasizes the catastrophic destruction of world, something that leads to the diminishment of hope and the impossibility of renewal: "As secularization spread its blight over American thought and life, the element of catastrophe remained - and intensifiedin apocalyptic thought while hope, its former concomitant diminished" (Maloney 448-9). Of course, secular apocalyptic beliefs provide nothing but despair. As Wojcik observes, "most secular beliefs about imminent apocalypse are devoid of the component of worldly redemption and therefore tend to be characterized by a sense of hopelessness and despair" (4). 
It was not until the aftermath of World War II that post-apocalyptic fiction has worked its way into western literature. The deployment of the nuclear bomb in Hiroshima in 1945 sparked a transformation in the way writers looked at the world. According to Booker, the years 1945 to 1964 were "the Golden Age of nuclear fear"(5), an age in which many fictional works became interested in exploring an apocalypse that was caused by a nuclear attack. "The creation and proliferation of nuclear weapons," as Wojcik notes, "have fundamentally altered contemporary apocalyptic thought, fueling fears of global annihilation and evoking widespread fatalism about the future of humanity" (1).

Obviously, a number of modern and post-modern Western novelists considers the threat of nuclear weapons the final apocalypse from which there would be no easy recovery. Martin Amis, for instance, states that:

Nuclear weapons could bring about the Book of Revelation in a matter of hours; they could do it today. Of course, no dead will rise; nothing will be revealed....Events that we call "acts of God"-floods, earthquakes, eruptionsare flesh wounds compared to the human act of nuclear war: a million Hiroshimas. (27)

The growing awareness of the possibility of nuclear dangers has apparently caused widespread fear and anxiety. For Curtis, this fear is vividly described by post-apocalyptic fiction where "the catharsis of seeing total destruction either relieves that fear or awakens a need to act to prevent it" (5).

In the aftermath of World War II the apocalyptic rhetoric inflames American imagination attracting the 


\section{Things Fall Apart: Post-Apocalyptic Vision in Cormac}

McCarthy's The Road

attention of millions of Americans. Manjikian makes it clear that "there is a consensus that apocalyptic theorizing is both on the increase and [is] an activity which now appeals to mainstream Americans - rather than being exclusively the province of...religious fundamentalists or survivalists" (6). Noticeably, the fictional works of that era reflect the tendency to shift from the long apocalyptic tradition to a post-apocalyptic world, one in which "another tone determines life, a tone born out of the world of ruins" (qtd. in Detweiler 153).

Indeed, many postmodernists have employed the genre of post-apocalyptic fiction as an attempt to cope with the violent changes of a world on the brink of an apocalypse, a postmodern world in which there is "an overriding sense of a chaotic, indifferent, and possibly meaningless universe" (Rosen XIV-XV). It is no wonder, then, that a number of novels written after World War II would employ the postapocalyptic literary genre both to express an adjustment to the abrupt "transition in space and time from an Old to a New World" (Rosen 2) and "to reveal the ways in which this genre of fiction appeals to our fears and our desire to begin again" (Curtis 12).

Curtis grapples for an exact definition of postapocalyptic fiction. What makes a work apocalyptic? She very concisely and clearly defines this kind of fiction as:

... any account that takes up how humans start over after the end of life on earth as we understand it. The apocalyptic event or events cause a radical shift in the basic conditions of human life; it does not require the destruction of all humans or even the destruction of all potential conditions of human life. The end 
may occur either through natural or human made causes. (5)

With Curtis, the immediate emphasis is obviously on 1) the possibility of starting over which provides the impetus for the story, 2) the aftermath of apocalyptic event, and 3) the absence of "divinely sanctioned ends" (5).

It is evident from these points that post-apocalyptic fiction is not interested in the immediate revelation of the catastrophic event itself; instead, it considers the aftermath of the cataclysmic end. If apocalyptic fiction emphasizes both catastrophe and renewal, post-apocalyptic fiction focuses particularly on the complex dynamics that affect the survivors' actions and decisions as well as on "possibility of starting over." According to Curtis, "starting over always has the hope of something better" because it "produces a radically different mindset than the mindset focused on the cataclysmic ending" (4). It is not odd therefore that "starting over can be the instigation for utopian imagining" (4). However, the utopian dreams may lead to a dystopian end. Noticeably, within the genre of post-apocalyptic fiction is a subgenre referred to as dystopian post-apocalyptic fiction. A post-apocalyptic novel can be thought of as dystopian when "there is no opportunity for starting over," and when "the apocalyptic event is largely insoluble and the life that emerges from it illustrates a critical dystopia that warns us of where we might be heading" (Curtis 7).

Furthermore, Curtis provides the following "traditional script" that a post-apocalyptic novelist could draw upon.

Inherent in all of these accounts is the necessary other: the groups of people who do not react so well to the cataclysm. These people, who seem to band up far more quickly

ELLS Vol.X No.I (257) December 2016


than our survivors, are bent on continued destruction (despite the irrationality of this). So roving bands of cannibals terrorizing the countryside emerges as a threat from which our pair of survivors must find escape...Thus the typical post-apocalyptic novel uses the threat to the safety of the small collection of survivors to cement their ties and to push those survivors into a more self-consciously organized system. Thus, such post-apocalyptic accounts climax in the defeat of the cannibals and end on the note of hope as the small community learns of the existence of other like minded communities across the country and from which the country will rise again. (8)

Although post-apocalyptic fiction often expresses hopes for beginning anew, it should be noted that it is not necessary for the post-apocalyptic novel to promise a new beginning since the new world is not a utopian, perfect one, but it has its own difficulties or challenges.

Cormac McCarthy's The Road lives up to the definition of post-apocalyptic fiction quite blatantly. Set in a post-apocalyptic future, The Road tells of a father and a son who remain nameless throughout the story and who undertake a perilous journey in order to survive in a postapocalyptic America, a place that has been reduced to a wasteland or wilderness in the wake of an unspecified apocalyptic event. To be sure, this is a post-apocalyptic world where "all marks of civilization have been removed or altered" (Estes 48). As is typical of the post-apocalyptic novel, the events of The Road "are set after the apocalyptic event" (Curtis 18). The cataclysmic event itself is not the 
point. What is more important is the destructive impact of the event itself, the aftermath. In McCarthy's novel, the revelation or unveiling, as one of the generic features of traditional apocalypse, is skillfully employed to create a straight linear plot that contains "a sequence of episodes, each structured according to the model of appearances, signs, which are also obstacles or veils. Each veil must be lifted to reveal a truth behind which always turns out to be another episode, another veil, to be lifted in its turn" (Miller, Heart 48).

The Road describes man's existence in a world devastated by a presumed nuclear war. Indeed, it is as early as the first three sentences that McCarthy's novel establishes a post-apocalyptic mood that permeates the whole work.

When he woke in the woods in the dark and the cold of the night he'd reach out to touch the child sleeping beside him. Nights dark beyond darkness and the days more gray each one than what had gone before. Like the onset of some cold glaucoma dimming away the world. (3)

The author describes this scene to Oprah Winfrey "as the genesis of the novel" (Cormac, Interview). In a post-nuclear world, the man and his son undergo a frightening experience where the unrelieved darkness and "the eternal blackness" encompass the whole crumbling world around them. This utter darkness encompasses and eclipses the daytime with something like "long gray dusks," or "long gray dawns" (7).

It should be noted that the darkness that is associated with both the nighttime and the daytime is used metaphorically to represent the unknown which is unpredictable and hence makes life either unknown or uncertain. Darkness may also refer to "the end of all things," to a world falling apart. In this case, darkness could be 
identified "with death" (Miller, Poets 31). Echoes of William Butler Yeats show up repeatedly in McCarthy's novel. The following lines from Yeats's "The Second Coming" perhaps sum up McCarthy's perilous world:

The blood-dimmed tide is loosed, and everywhere

The ceremony of innocence is drowned;

The best lack all conviction, while the worst

Are full of passionate
intensity.

Yeats's poem takes as its theme a cataclysmic event that causes everything to fall apart. These lines describe what it means for things to fall apart; a tide studded with blood is "loosed" or released leading everything to their doom or death. Just as this tide drowns bodies, so, too, does it signify a loss of innocence. Moreover, whereas wise people experience agonizing uncertainty about life, the worst become fervent and, seemingly, powerful.

The fear of the darkness which symbolizes the unknown or the uncertainty and lack of direction is reinforced in the father's dream in the opening paragraph of McCarthy's novel. It is a dream that describes how the father "had wandered in a cave where the child led him by the hand" (3). In the cave the father and his son confront a "creature that raised its dripping mouth from the rimstone pool and stared into the light with eyes dead and white and sightless as the eggs of spiders" (3). The cave may be symbolic of the darkness that eclipses the light of knowledge and civilization. Like the cave, the post-apocalyptic world 
has become a hiding place for monsters or hunters who participate in mysterious and illicit practices. In a wider sense, it may also refer to the father's desire to help his son explore the darkness of the unknown: "No matter what. I will not send you into the darkness alone" (150). This explains why the father thinks that the child is his "warrant" for pervading the darkness of the future world or "the word of God" (4) that will guide him back to light and civilization.

The Road is a typical post-apocalyptic novel in that 1) human existence is radically transformed by an unnamed cataclysmic event, 2) fear of imminent doom is the underlying theme of the novel, 3) the possibility of starting over, 4) the absence of divinely sanctioned ends. In the first place, The Road opens with a description of the immediate circumstances of the cataclysmic event that leaves the country lifeless. The setting for this novel is a lifeless and utterly devastated landscape. The man and his son decide to move into the South in search of the possibilities of human life. In his exploration of "the country to the south," the father finds it "barren, silent, godless" (4). Moreover, an allconsuming fire has destroyed the countryside through which the man and the boy move leaving the "soft ash" everywhere.

On the far side of the river valley the road passed through a stark black burn. Charred and limbless trunks of trees stretching away on every side. Ash moving over the road and the sagging hands of blind wire strung from the blackened lightpoles whining thinly in the wind. A burned house in a clearing and beyond that a reach of meadow-lands stark and gray and a raw red mudbank where a roadworks lay abandoned. (7)

ELLS Vol.X No.I (261) December 2016


Obviously, the fire has transformed the landscape into burned valleys of ashes "carried on the bleak and temporal winds to and fro in the void" (9). Worse, the American states are not specifically identified any more; the father makes it clear that "there's not any more states" (36).

McCarthy stresses the fear of the unknown as an essential characteristic of all post-apocalyptic novels. In The Road, it is very hard not to see innumerable appalling scenes that describe the aftermath of "the late world".

The city was mostly burned. No sign of life.

Cars in the street caked with ash, everything covered with ash and dust. Fossil tracks in the dried sludge. A corpse in a doorway dried to leather. Grimacing at the day. (10)

Wherever they go, the father and the son can see chaos, death, fear, and destruction: the landscape is littered with "mummied figures" or "Human bodies. Sprawled in every attitude. Dried and shrunken in their rotted clothes" (40), the roads are "peopled with refugees shrouded up in their clothing" (24), the sea is covered with "bones of seabirds" (187), the sun is "moving unseen beyond the murk," flora and fauna are "burned away," and "the slow darkness falling over everything" (39). Indeed, with the extinguishing of fires, "the only thing that moved in the streets was the blowing ash" (21).

Although the old world of the father has already been destroyed, buildings are partially burnt but extraordinarily intact: "Everything as it once had been save faded and weathered" (7). As is to be expected, the surviving buildings are supposed to provide both the father and the son with food and shelter. Nevertheless, these buildings become places of dread and fear, emphasizing fear as one of the main premises 
of post-apocalyptic fiction. Noticeably, the father intuitively breaks into these buildings in search of food, only to find unspeakable horrors. When he tries to break into a building, he is terrified by seeing "an army" of cannibals:

$\ldots$ in tennis shoes, tramping. Carrying threefoot lengths of pipe with leather wrappings. Lanyards at the wrist....They clanked past, marching with a swaying gait like wind-up toys. Bearded, their breath smoking through their masks.... Behind them came wagons drawn by slaves in harness and piled with goods of war and after that the women, perhaps a dozen in number, some of them pregnant, and lastly a supplementary consort of catamites illclothed against the cold and fitted in dogcollars and yoked each to each. (78)

This is not the only unbearable fearful experience they undergo. They experience a difficult or terrifying series of events. Even when the father slips into visions or dreams, he sees himself living in a post-apocalyptic world peopled with unimaginable repeated images of:

Shapes of dried blood in the stubble grass... where the slain had been field-dressed and hauled away. The wall beyond held a frieze of human heads, all faced alike, dried and caved with their taut grins and shrunken eyes. They wore gold rings in their leather ears and in the wind their sparse and ratty hair twisted about on their skulls. The teeth in their sockets like dental molds, the crude tattoos etched in some homebrewed woad faded in the beggared sunlight. Spiders, swords, targets. A dragon. Runic slogans, creeds misspelled. Old 
scars with old motifs stitched along their borders. The heads not truncheoned shapeless had been flayed of their skins and the raw skulls painted and signed across the forehead in a scrawl and one white bone skull had the plate sutures etched carefully in ink like a blueprint for assembly. (76)

In this wasteland what is left is only fear. In fact, this is a post-apocalyptic world that is "largely populated by men who would eat your children in front of your eyes" (152), a world where one can easily see "a charred human infant headless and gutted and blackening on the spit" (167).

The father is fully aware that he and his son exist in a dangerous world, one that is fueled by fear and horror. Indeed, he was wrong when he mistakenly refers to himself and his wife in the aftermath of the apocalyptic event as "survivors." His wife, who committed suicide earlier to release herself from constant fear, is rightly suspicious: "What in God's name are you talking about? We're not survivors. We're the walking dead in a horror film" (47). Her abiding fear is that she might be captured by cannibals: "Sooner or later they will catch us and they will kill us. They will rape me. They'll rape him. They are going to rape us and kill us and eat us and you wont face it. You'd rather wait for it to happen. But I cant. I cant" (48).

In fact, this dangerous world manifests itself in yet another horrible scene in which human beings are trapped in their selfish attitudes. The people of this post-apocalyptic world are divided into two classes; "good guys" or the hunted and "bad guys" or the hunters. The father and his son come face to face with the forbidden activities of the bad guys when they search for food in "a once grand house sited 
on a rise above the road" (89). Entering into the dark cellar of the house, the man finds "naked people, male and female, all trying to hide, shielding their faces with their hands. On the mattress lay a man with his legs gone to the hip and the stumps of them blackened and burnt. The smell was hideous" (93). Indeed, it does not take the father long to be fearful and highly suspicious of everyone because they have become killers, and he is unable to distinguish friend from foe.

The various cannibalistic practices show the man and the boy that human connections are severed in such a postapocalyptic world. The exchange between the boy and the man about the organized bands of cannibals who imprison the "naked people" contains the essence of this violent world.

They're going to kill those people, arent they?

Yes.

Why do they have to do that?

I dont know.

Are they going to eat them?

I dont know.

They're going to eat them, arent they?

Yes.

And we couldnt help them because then they'd eat us too.

Yes.

And that's why we couldnt help them.

Yes.

Okay. (107) 


\section{Things Fall Apart: Post-Apocalyptic Vision in Cormac}

McCarthy's The Road

The conclusion the boy draws from this is that both he and his father may be held prisoners by the cannibalistic "bad guys."

In many ways the death of the pre-apocalyptic world is remarkably similar to that of the father who is not attuned to the post-apocalyptic world, an unknown world in which everything becomes a hostage to oblivion:

The world shrinking down about a raw core of parsible entities. The names of things slowly following those things into oblivion. Colors. The names of birds. Things to eat. Finally the names of things one believed to be true. More fragile than he would have thought. How much was gone already? The sacred idiom shorn of its referents and so of its reality. Drawing down like something trying to preserve heat. In time to wink out forever. (75)

The father, as has been pointed out, wrestles with the aftermath of the violent destruction of his old world. He is always in danger, and there is a growing sense of death all around him. Indeed, the father awaits his turn to be swept up by the darkness and the silence of this new world. Reflecting on his life, he now is able to see clearly a man looking "like something out of a deathcamp. Starved, exhausted, sick with fear" (99).

In fact, the father does not fit neatly into this postapocalyptic world. As the narrator explains, "Maybe he understood for the first time that to the boy he was himself an alien. A being from a planet that no longer existed" (129). Obviously, he feels that he is not part of this world because he has lost all his friends and acquaintances that lived the experience of the pre-apocalyptic world. As Hage observes, 
"Everything that was once familiar-loved ones, friends, a morning sunrise, nature, and the very lineaments of life as he knew it-has perished. Even his own identity and the identity of those few that still remain alive have dissolved in this post-apocalyptic oblivion" (103). The boy's exchange with the father about the latter's lifelong friends is meant to foreshadow the father's impending death.

Did you have any friends?

Yes. I did.

Lots of them?

Yes.

Do you remember them?

Yes. I remember them.

What happened to them?

They died.

All of them?

Yes. All of them.

Do you miss them?

Yes. I do. (51)

The man has lost all the people who used to share him a common experience.

Curtis demonstrates that "in recognition of the rules of the genre writers of post-apocalyptic fiction take care to explain the mechanisms of destruction" (17). Therefore, the novelist describes in detail a post-apocalyptic world where the father and his son are left waiting for their doom. The cataclysm has sent everything that belongs to the father's world into oblivion: "The winds had swept the ash and dust from the surface. Rich lands at one time. No sign of life 
anywhere. It was no country that he knew. The names of the towns or the rivers" (170). There is no way to live in a world with no sense of the past. Worse, he is not able to draw on his memory to show him the way to salvation.

Indeed, his fading memories do not help him make sense of a post-apocalyptic world. According to Eudora Welty,

...the memory is not meant to freeze the past into something impervious to new experience. Instead, it repeatedly redefines the patterns of our lives as we reach a fuller understanding; the body of all we know alters slightly with each new addition as memory works its magic. (Mortimer 166)

In fact, in the case of the father, memory puts a kind of hold on his present and at the same time fails to reconstruct the vanished world. With the specter of death hovering nearby, he "thought about his life but there was no life to think about" (200).

For the father, there are several reasons for not believing in the value of his own life. In fact, he contemplates suicide several times. What opens him up to life is "a sort of personal manifest destiny to protect the child" (Hage 103). The narrator concludes "That the boy was all that stood between him and death" (25). Moreover, the father confesses that his duty or responsibility is to take good care of his child, intervening at critical moments to save him: "My job is to take care of you. I was appointed to do that by God. I will kill anyone who touches you" (65). It is not surprising, then, that this father often teaches his son to take his own life in case he falls into the hands of cannibals or 
flesh-eaters: "If they find you, you are going to have to do it. Do you understand? Shh. No crying. Do you hear me? You know how to do it. You put it in your mouth and point it up. Do it quick and hard" (95). According to Maslin, McCarthy's novel is "illuminated by extraordinary tenderness....The father's loving efforts to shepherd his son are made that much more wrenching by the unavailability of food, shelter, safety, companionship or hope in most places where they scavenge to subsist" (8). Thus, the father is defined by his overly protective actions toward his son, actions which would stamp him as a truly "good guy."

As discussed earlier, one of the fundamental themes that leads us to classify McCarthy's novel as postapocalyptic is the radical transformation of the world after an apocalyptic destruction, a profound transformation that gives voice to anxiety and fear which are central to a postapocalyptic novel. Another motif found in post-apocalyptic fiction is the absence of "divinely sanctioned ends." Obviously, the catastrophic end event in The Road is not a religious event, but it is man-made. The hypothesis that "the United States will be destroyed because it has become a nation of sin and increasing paganism" (Wojcik 76) could not be applied to McCarthy's novel. Obviously, The Road is a narrative in which man is the underlying cause of the apocalypse that would cause his own destruction. David Ketterer declares that apocalypse is

...a legitimate topic of unavoidable concern, particularly today, when fictive intimations of catastrophe gain credibility from the existence of nuclear weapons. For the first time, man has it in his power to be the instigator of a doit-yourself apocalypse. (4) 


\section{Things Fall Apart: Post-Apocalyptic Vision in Cormac}

McCarthy's The Road

As discussed in the introduction to this paper, the apocalyptic destruction of the world, according to the classical or primitive apocalyptic traditions, ushers in a new world, a "New Jerusalem," or a "New Heaven on Earth in which the saved will live eternally with God" (Rosen xiv). This simply means that everything will be restored to an original state through this destructive but creative process. Unlike the classical apocalyptic world, the post-apocalyptic world of The Road is a "godless" realm where the protagonist cannot look to the sky for help. This is most evident early on in the story when the protagonist kneels "in the ashes" and immediately raises his face up toward the sky to question God:

He raised his face to the paling day. Are you there? He whispered. Will I see you at the last? Have you a neck by which to throttle you? Have you a heart? Damn you eternally have you a soul? Oh God, he whispered. Oh God. (10)

Thus, the protagonist expresses the need for some kind of salvation, one that he fails to achieve.

In addition, after walking down the road for days, he finally comes to the conclusion that "On this road there are no godspoke men. They are gone and I am left and they have taken with them the world" (4). The old man, whom the father and the son run into, further emphasizes that "there is no God" (143). This response recalls that of Beckett's Hamm in Endgame when Hamm fervently prays to God for salvation only to find that "He doesn't exist!" (40). Given that the protagonist of The Road lives in a "barren, silent, godless" world, it is not likely for the novel to have a divinely prescribed ending, an ending in which "God 
intervenes to restore order to a disordered world" (Rosen $\mathrm{XV})$.

The possibility of starting over is another generic feature that is enough to give the post-apocalyptic label to a fictional work. This is where the novelist answers the question: Is there a possibility for starting over in an alien world? According to Curtis, a post-apocalyptic novel has to "focus particularly on the idea of starting over" (3), an idea that "always has the hope of something better" (4). The Road ends with the father physically ruined by what is presumably tuberculosis, a disease that gets much worse over time and eventually kills him. The father's death puts the boy at the mercy of the cannibalistic predators. Oddly enough, the boy is miraculously saved by a family that belongs to the "good guys," thereby protecting him from certain death.

As noted earlier, the father's demise has been directly concomitant with the destruction of the old world. For the father, there is no way to go back to the vanished world. Nor is there a way to reconstruct another world over "the ashes of the late world" (9). In the novel's closing paragraph, the protagonist is haunted by his memories. In fact, memory does not act as a bridge or a pathway to the future, but it is used to focus on a world that has fallen apart, one that can "Not be made right again":

Once there were brook trout in the streams in the mountains. You could see them standing in the amber current where the white edges of their fins wimpled softly in the flow. They smelled of moss in your hand. Polished and muscular and torsional. On their backs were vermiculate patterns that were maps of the world in its becoming. Maps and mazes. Of a

ELLS Vol.X No.I (271) December 2016


thing which could not be put back. Not be made right again. In the deep glens where they lived all things were older than man and they hummed of mystery. (241)

This passage is rich in its depiction of an irretrievably lost nature. The fish were once there, but they now exist only as memories. The brook trout symbolizes the "vanished world." The "maps of the world in its becoming" are not just difficult but indecipherable puzzles that speak of a dead world. In this novel, what remains is only the sense of "a thing which could not be put back" (241).

Overall, the ending of McCarthy's novel conveys an uncompromising vision that does not seem to offer an "opportunity for starting over." The question is: Does the boy, who is about six years old, give the novel a hopeful ending that suggests the possibility of renewal and starting over? As mentioned earlier, the father makes his most optimistic prediction about the boy when he declares that the boy is "his warrant" as well as "the word of God" (4). In accordance with the father's expectation, William Kennedy describes the boy as a "designated but unsubstantiated messiah" because he is not infused with faith that will enable him to accomplish his messianic role. Thus, Kennedy expresses disappointment in McCarthy's tendency to present the boy as "a designated but unsubstantiated messiah," someone of whose "mission-redeeming a dead world, outliving death-nothing is said" (Kennedy). However, several references are made to suggest that the boy is a messianic figure: "he is an untainted boy, unpolluted by the once-dominant humanity that brought about its own end. He is driven by a deep and abiding compassion for all he encounters" (Hague 52). In addition, Spurgeon points out

\begin{tabular}{llll}
\hline \hline ELLS Vol. N No.I & (272) December 2016
\end{tabular}


that the boy "has no memory of...that lost world, nonetheless maintains a purity of moral vision" (17). Born after the cataclysm, the boy "is a sort of pure boy and a blank slate" (Hague 143). This makes the boy "the reference point against which everything else is considered" (Spurgeon 139).

The father's belief in the goodness and "the sanctity of his son" stresses "the inevitability that the boy will be 'lucky' after the man's death" (Spurgeon 148). Indeed, the boy's final survival offers a faint glimmer of hope or a possibility of starting over. However, the question is: Can the boy's goodness shield him from the turbulence of the world that has proven to be unmanageable? Discussing Wharton's The House of Mirth, Gargano concludes that "Goodness and the freedom to achieve it are commodities too fragile to survive in such a civilized social state" (139). If goodness is not likely to survive in "a civilized social state," it seems unlikely to be realized or kept in a postapocalyptic world "where being gang-raped and eaten by roving bands of cannibals is only one item on a terrifyingly long list of unpleasant ways to die" (Spurgeon 18). Like his father, the boy moves in a landscape inhospitable to human beings with no purpose or destination, a major thematic concern for McCarthy.

Noticeably, the boy does not leave himself open to new explorations away from the world of the father: "He tried to talk to God but the best thing was to talk to his father and he did talk to him and he didnt forget" (241). The father is literally deceased, but the boy still follows his father's map to discover his own road. Therefore, he will go wherever the road-described by his father as a "black shape" that is "running from dark to dark" ( )-leads. Significantly, on that road the boy finds nothing but signs of man's history which will soon vanish from sight. This

\begin{tabular}{llll}
\hline ELLS Vol.X No.I (273) December 2016
\end{tabular}


Things Fall Apart: Post-Apocalyptic Vision in Cormac

McCarthy's The Road

echoes William Stafford's perspective of the road in "At the Bomb Testing Site":

At noon in the desert a panting lizard

waited for history, its elbows tense,

watching the curve of a particular road

as if something might happen.

It was looking for something farther off

than people could see, an important scene

acted in stone for little selves

at the flute end of consequences.

Unlike the boy, the lizard's journey on the road leads her to real answers for the future. Awaiting "history," the lizard envisions a post-apocalyptic landscape in which man's foolish actions will put an end to civilization. The exchange between the man and the boy underscores the essential truth that the road will not remain long:

But the roads are still there.

Yes. For a while.

How long a while?

I dont know. Maybe quite a while. There's nothing to uproot them so they should be okay for a while. (37)

Although "there's not a lot of good news on the road" (147) in a post-apocalyptic world, the boy keeps his eyes on the road as a way of finding a direction or a purpose.

As the title of the novel suggests, much of the action takes place on the road, demonstrating most clearly how the road can never be taken as a permanent refuge; rather, it is only a means of survival. Indeed, on the road, the boy is only 
preoccupied with survival more than with imagining a different better future. However "there is no chance of long term survival in a world where a handful of humans are the only living entities" (Curtis 36). Apparently, this postapocalyptic vision is not driven by a utopian impulse. Rather, it is a bleak vision that never helps the man or the boy see things anew, a bleakness that is faintly mixed with hope that may turn out to be illusory. In a significantly titled article "The Road Through Hell, Paved With Desperation," Maslin writes:

"The Road" would be pure misery if not for its stunning, savage beauty. This is an exquisitely bleak incantation-pure poetic brimstone. Mr. McCarthy has summoned his fiercest visions to invoke the devastation...."The Road" offers nothing in the way of escape or comfort. But its fearless wisdom is more indelible than reassurance could ever be.

Obviously, struggle for survival is a necessary aspect of predatory world. However, in McCarthy's post-apocalyptic world, survival is no longer a possibility.

Indeed, Cormac McCarthy's The Road may be more fruitfully approached via the post-apocalyptic genre, which was widely popularized through American fiction in the aftermath of World War II. It is clear that The Road contains a post-apocalyptic vision that elevates its author's stature among postmodern novelists. According to Miller, "the act of unveiling" is the most important thing about the apocalypse. Accordingly, The Road uncovers or unveils the primitive elements that remain hidden or disguised within the human psyche. It fleshes out human beings as they really 
are, detailing how they regress into primitive lifestyles and practices which drive them to struggle for mere survival.

In conclusion, The Road contains all the elements that make a fictional work post-apocalyptic. First, the novel does not focus on the pre-apocalypse. Rather, it starts with an exploration of the highly destroyed landscape created by the cataclysm. Second, the main characters are paralyzed by constant fear and apprehension. Third, there is a possibility of starting over, albeit limited. Fourth, the ending of the novel is not divinely prescribed because modern secular apocalypse does not consider God or religion as a means of understanding post-apocalyptic world, a world in which particular emphasis is given to the catastrophic destruction and its concomitant diminishment of hope and impossibility of renewal. Furthermore, the novel, which is uninterrupted by chapter breaks, "moves like its characters - slowly and deliberately, earthbound, irrevocably tied to an utterly burnt and devastated landscape" (Spurgeon 16). 


\section{Works Cited}

Amis, Martin. "Introduction: Thinkability." Einstein's Monsters. New York: Harmony Books, 1987. 1-29. Print.

Booker, M. Keith. Monsters, mushroom clouds, and the Cold War: American Science Fiction and the Roots of Postmodernism, 1946-1964. Westport, Connecticut: Greenwood Press, 2001. Print.

Collins, John. J. The Apocalyptic Imagination: An Introduction to Jewish Apocalyptic Literature. Michigan: Grand Rapids, 1998. Print.

Detweiler, Robert. "Apocalyptic Fiction and the End(s) of Realism." European Literature and Theology in the Twentieth Century: Ends of Time. Ed. David Jasper and Colin Crowder. Hampshire: Macmillan, 1991.153-183. Print.

Estes, Andrew Keller. Cormac McCarthy and the Writing of American Spaces. Amsterdam: Rodopi, 2013. Print.

Gargano, James. "The House of Mirth: Social Futility and Faith." American Literature 44.1 (1972): 137-143. Print.

Glasson. T. F. ed. The Revelation of John. The Cambridge Bible Commentary on the New English Bible. Cambridge: Cambridge University Press, 1965. Print.

Hage, Erik. Cormac McCarthy: A Literary Companion. Jefferson, N.C.: McFarland \& Company, 2010. Print

Kennedy, William. "Left Behind." The New York Times Book Review. 10 July 2006. Web. 6 December 2015.

Ketterer, David. New Worlds For Old: The Apocalyptic Imagination, Science Fiction, and American Literature. Bloomington: Indiana University Press, 1974. Print.

Maloney, Stephen Rev. of Toward a New Earth: Apocalypse in the American Novel, by John R. May. The Georgia Review 27.3 (1973): 447-451. Print.

Manjikian, Mary. Apocalypse and Post-politics: The Romance of the End. Lanham, MD: Lexington, 2012. Print. 


\section{Things Fall Apart: Post-Apocalyptic Vision in Cormac}

McCarthy's The Road

Maslin, Janet. "The Road through Hell, Paved with Desperation." The New York Times, September 25, 2005, p. E1. Print.

May, John R. Toward a New Earth: Apocalypse in the American Novel. Notre Dame: University of Notre Dame Press, 1972. Print.

McCarthy, Cormac. The Road. New York: Knopf, 2006. Print.

---. Interview, Oprah Winfrey. "The Cormac McCarthy Interview." 22 Feb. 2009. Web. 6 December 2015.

Mikics, David. A New Handbook of Literary Terms. New Haven: Yale University Press, 2007. Print.

Miller, J. Hillis. Poets of Reality; Six Twentieth-Century Writers. Cambridge: Belknap Press of Harvard University Press, 1965. Print.

---. "Heart of Darkness Revisited." Conrad's Heart of darkness and contemporary thought: revisiting the horror with Lacoue-Labarthe. Ed. Nidesh Lawtoo. New York: Bloomsbury. 2012. 17-54. Print.

Mortimer, Gail. L. Daughter of the Swan: Love and Knowledge in Eudora Welty's Fiction. Athens, GA: University of Georgia Press, 1994. Print.

Robinson, Douglas. American Apocalypses. Baltimore: John Hopkins University Press, 1985. Print.

Rosen, Elizabeth. Apocalyptic Transformations: Apocalypse and the Postmodern Imagination. Lanham, Maryland: Lexington Books, 2008. Print.

Ryan, Tom. "Cormac McCarthy's Catholic Sensibilty." The Free Library. 2007. Web. 6 December 2015.

Smee, Sebastian. "When all the clocks have stopped." The Spectator, 2006. Web. 6 December 2015.

Spurgeon, Sara L. "Introduction." Cormac McCarthy: All the Pretty Horses, No Country for Old Men, The Road. Ed. Sara L. Spurgeon. London: Continuum, 2011. Print.

Timberg, Scott. "Shameless Pleasures." Los Angeles Times, 2008. Print. 